\title{
PENGARUH KONFLIK PEKERJAAN-KELUARGA TERHADAP KESEJAHTERAAN
}

\author{
Rikha Muftia Khoirunnisa' \\ Universitas Ahmad Dahlan \\ e-mail: move.tya@gmail.com
}

\begin{abstract}
ABSTRAK
The most important domain on someone's life are work and family. Everyone have specific roles on it, and ideally he/she trying to balance it. But, it will lead workfamily conflict as the demand is incompatible each other. Based on role theory, workfamily conflict affect someone's well-being. Well-being indicate someone's happiness and sobriety, so it's important to concern on it. In the current research, work-family conflict identified into two form, i.e. time-based and strain-based conflict. While wellbeing measured by job and family satisfaction. Data collected using survey method. The respondents in the current research are headmasters. Data of perceived workfamily conflict gained from couple's perceive (dyadic). It is aimed to get more valid data about perceived work-family conflict, which rarely done in the prior researches. In the current research, the hypotheses testing used multiple regression analysis. Results showed that only strain-based conflict negatively affect job satisfaction.
\end{abstract}

Keywords: couples, emotional intelligence, family satisfaction, job satisfaction, strainbased conflict, time-based conflict, well being, work-family conflict

\section{PENDAHULUAN}

Kehidupan pekerjaan dan keluarga merupakan dua domain aktivitas manusia dimana orang menghabiskan dua per tiga hidupnya dalam dua domain tersebut (Nollen, 1986). Setiap individu memiliki peran dalam masingmasing domain tersebut dan berusaha untuk dapat memenuhi perannya. Namun, ketika salah satu peran menuntut perhatian yang lebih akan mengganggu pemenuhan peran yang lain. Hal ini sesuai dengan teori peran yang menyatakan bahwa seseorang memiliki lebih dari satu peran dalam kehidupannya, sementara itu energi dan waktu seseorang terbatas. Semakin banyak peran yang dimiliki seseorang, akan semakin besar kemungkinan munculnya ketidaksesuaian antar peran. Ketidaksesuaian peran-peran tersebut memunculkan konflik pekerjaan-keluarga yang merupakan bentuk dari konflik antar peran (Greenhaus dan Beutell, 1985). Konflik pekerjaankeluarga menunjukkan terganggunya usaha seseorang dalam memenuhi, menyeimbangkan, dan mengoptimalkan perannya dalam pekerjaan dan keluarga yang dipengaruhi oleh tekanan atau tuntutan baik dari pekerjaan maupun keluarga.

Penelitian-penelitian terdahulu mengenai konflik pekerjaan-keluarga menunjukkan bahwa konflik pekerjaan-keluarga berpengaruh terhadap kesejahteraan, yaitu kepuasan kerja (Ahmad, 1996; Noor, 2002; Grandey et al., 2005; Lambert et al., 2006; Ibrahim dan Marri, 2008) dan kepuasan keluarga (Ahmad, 1996; Ibrahim dan Marri, 2008). Konflik pekerjaankeluarga menyebabkan seseorang tidak dapat memenuhi perannya secara optimal (pemenuhan peran terganggu atau terhambat), yang kemudian akan menyebabkan kesejahteraannya terganggu. 
Kesejahteraan merupakan kepuasan dan atau gangguan dalam kehidupan seseorang. Kesejahteraan digambarkan dalam bentuk kepuasan pada domain utama individu (Baruch dan Barnett, 1986). Kesejahteraan hidup sangat berhubungan dengan kebahagiaan, ketenangan, dan ketentraman hidup yang dirasakan. Kesejahteraan dalam domain pekerjaan diukur dengan kepuasan kerja, sebagaimana pendapat Singh dan Woods (2008) bahwa kepuasan kerja dikonseptualisasikan sebagai sesuatu yang menunjukkan kesejahteraan pada pekerjaan. Sedangkan kepuasan keluarga mewakili kesejahteraan pada domain keluarga, yang menggambarkan perasaan seseorang tehadap keluarga terkait dengan pemenuhan peran dalam keluarga. Penelitian ini menggunakan kepuasan kerja dan kepuasan keluarga untuk mengukur kesejahteraan seseorang karena kedua pengukuran ini mencerminkan keseluruhan kualitas hidup seseorang (Parasuraman et al., 1992).

\section{REVIEW LITERATUR DAN HIPOTESIS}

\section{Peran}

Setiap individu memiliki dua domain yang paling utama dalam hidupnya, yaitu keluarga dan pekerjaan. Masing-masing domain menuntut pemenuhan peran. Peran adalah sekumpulan ekspektasi mengenai perilaku pada suatu posisi dalam struktur sosial (Rizzo et al., 1970). Seseorang akan berusaha untuk memenuhi dan menyeimbangkan peran pada domain pekerjaan dan keluarga. Namun pada kenyataannya, kebanyakan orang mengalami kesulitan dalam menyeimbangkan berbagai peran yang dimilikinya. Hal ini dijelaskan dengan teori peran, yang menyatakan bahwa seseorang memiliki peran lebih dari satu dalam kehidupannya, sementara itu energi dan waktu sangat terbatas. Tuntutan dari masing-masing peran yang tidak sesuai akan memunculkan konflik, yang disebut sebagai konflik peran.
Konflik antar peran merupakan salah satu bentuk konflik peran yang terjadi karena tekanan yang muncul dalam suatu peran tidak sesuai dengan tekanan yang muncul pada peran yang lain (Greenhaus dan Beutell, 1985). Kahn et al. dalam Greenhaus dan Beutell (1985) menyebutkan konflik pekerjaan-keluarga merupakan bentuk konflik antar peran yang muncul karena tekanan peran dari domain keluarga dan pekerjaan satu sama lain tidak sesuai. Partisipasi dalam suatu peran menyulitkan pemenuhan peran yang lain.

\section{Konflik Pekerjaan-Keluarga}

Berdasarkan hipotesis keterbatasan/ scarcity hypothesis (Grant-Vallone dan Donaldson, 2001; Parasuraman dan Greenhaus, 2002; Greenhaus dan Powell, 2006) dalam teori peran, konflik pekerjaan-keluarga mempengaruhi kesejahteraan (Juariyah, 2006). Hipotesis ini mengasumsikan bahwa energi dan waktu manusia terbatas, sehingga individu yang berpartisipasi dalam peran ganda akan mengalami konflik antar peran yang tidak bisa dihindari (Grant-Vallone dan Donaldson, 2001). Karena energi manusia terbatas, kesejahteraan menjadi terganggu oleh konflik peran, kelebihan peran, dan ketidaksesuaian peran (Baruch dan Barnet, 1986). Dengan kata lain, konflik pekerjaan-keluarga berpengaruh negatif terhadap kesejahteraan.

Banyak penelitian telah dilakukan dalam topik konflik pekerjaan-keluarga. Berdasarkan berbagai hasil penelitian dapat ditarik kesimpulan bahwa hubungan konflik pekerjaankeluarga dan kesejahteraan dipengaruhi banyak faktor. Ketidakkonsistenan hasil penelitian mengenai hubungan langsung konflik pekerjaankeluarga dan kesejahteraan antara lain diduga karena masing-masing peneliti menggunakan pendekatan/sudut pandang yang berbedabeda, sehingga indikator yang digunakan juga berbeda-beda (beberapa menggunakan single measure, beberapa menggunakan pengukuran multidimensional) yang kemudian menyebabkan temuan yang tidak konsisten. 
Selain menggunakan indikator yang berbedabeda, metode yang digunakan juga berbedabeda. Kebanyakan menggunakan metode survei dan data persepsi konflik didapatkan melalui kuesioner yang diisi secara self-administered. Namun beberapa menggunakan metode yang lain, seperti longitudinal study dan menggunakan persepsi pasangan ( $d y a d)$ untuk mendapatkan data persepsi pasangan. Tingkat konflik yang dialami pada berbagai setting penelitian-penelitian tersebut juga berbeda-beda terkait dengan tuntutan pekerjaan yang juga berbeda pada masing-masing profesi (beberapa menggunakan responden blue-collar, white-collar, atau mahasiswa). Greenhaus dan Beutell (1985) mendefinisikan konflik pekerjaan-keluarga sebagai sebuah bentuk konflik antar peran dimana tekanan/ tuntutan peran dari pekerjaan dan keluarga tidak sesuai. Tekanan didefinisikan sebagai persepsi kinerja peran dan perasaan yang terdesak (Yang et al., 2000). Persepsi tekanan dapat berasal dari desakan untuk memenuhi harapan anggota lingkungan (tekanan objektif individual) dan desakan untuk memenuhi harapan individu secara personal (tekanan subjektif psikologis individual) (Kahn et al. dalam Yang et al., 2000). Konflik pekerjaan-keluarga meningkat ketika pekerjaan dan keluarga tumpang tindih melalui pengharapan satu sama lain, dan menyebabkan konflik pada diri individu yang mempengaruhi kualitas hidup (Lambert et al., 2006). Selain itu, konflik pekerjaan-keluarga juga meningkat ketika tuntutan peran pada domain pekerjaan dan keluarga juga meningkat (Cooke dan Rousseau, 1984).

Konflik pekerjaan-keluarga dibedakan menjadi konflik berdasarkan waktu dan ketegangan. Konflik berdasarkan waktu yaitu konflik yang terjadi karena waktu yang digunakan untuk memenuhi peran pada salah satu domain (pekerjaan atau keluarga), menghalangi waktu yang seharusnya digunakan untuk memenuhi peran pada domain lain (keluarga atau pekerjaan).
Penambahan waktu untuk memenuhi peran pada satu domain menghabiskan energi. Sumber konflik yang terkait dengan pekerjaan, antara lain: jumlah jam kerja setiap minggu, pergantian jam kerja secara berlebihan dan tidak teratur, dan jadwal kerja yang tidak fleksibel. Sumbersumber konflik yang berkaitan dengan keluarga, antara lain lamanya waktu yang dibutuhkan untuk menyelesaikan aktifitas-aktifitas bersama keluarga, mengasuh anak yang masih kecil, dan pola kerja pasangan suami-istri (Greenhaus dan Beutell, 1985).

Sedangkan konflik berdasarkan ketegangan merupakan konflik yang terjadi karena ketegangan yang muncul pada salah satu peran mempersulit pemenuhan peran pada domain lain. Sumber-sumber konflik yang berkaitan dengan pekerjaan, antara lain: kurangnya dukungan dan interaksi dengan rekan kerja, perubahan lingkungan kerja, berpartisipasi dalam aktifitas yang sangat mengikat, burnout terhadap pekerjaan, dan konsentrasi mental yang diperlukan pada pekerjaan (Greenhaus dan Beutell, 1985). Sumber-sumber konflik yang berhubungan dengan keluarga antara lain: perbedaan orientasi karir antara suami dan istri, ketiadaan dukungan dari pasangan suami atau istri, serta ketidaksepakatan antara suami dan istri mengenai peran-peran dalam keluarga (Greenhaus dan Beutell, 1985). Menurut MacEwen dan Barling (1988), ketegangan akan mengakibatkan munculnya emosi negatif, seperti mudah marah dan tersinggung. Bentuk ketegangan yang lain yaitu keletihan, depresi, dan apatis. Ketika seseorang mengalami kesulitan atau tidak dapat mengendalikan emosi negatifnya, menyebabkan kesejahteraan pada domain-domain tersebut menjadi terganggu.

\section{Kesejahteraan}

Kesejahteraan mencerminkan kepuasan dan atau gangguan dalam kehidupan seseorang, baik dalam domain pekerjaan maupun keluarga (Astuti, 2004). Secara umum, kesejahteraan 
diukur menggunakan tingkat kepuasan yang dipersepsikan secara subjektif terhadap kualitas peran-peran pada berbagai domain kehidupan (Frone et al., 1992). Sebagaimana yang telah disebutkan sebelumnya oleh Nollen (1986), keluarga dan pekerjaan merupakan dua domain aktivitas manusia dimana orang menghabiskan hidupnya dalam dua domain tersebut. Kehidupan orang dewasa terutama terpusat pada pekerjaan dan keluarga (Frone et al., 1992), sehingga kepuasan dalam domain pekerjaan dan keluarga menjadi penentu kepuasan hidup secara keseluruhan. Kepuasan kerja merupakan keadaan emosi yang senang atau emosi positif yang berasal dari penilaian pekerjaan atau pengalaman kerja seseorang (Locke dalam Lambert et al, 2006). Kepuasan kerja merupakan respon afektif karyawan terkait dengan pekerjaannya dalam organisasi yang merupakan hasil perbandingan secara keseluruhan yang dilakukan oleh individu mengenai hasil yang dia harapkan, butuhkan, inginkan, atau rasakan dengan keadilan (Cranny et al. dalam Lambert et al., 2006). Alasan pentingnya memperhatikan kepuasan kerja yaitu kepuasan kerja mempengaruhi fungsi organisasi (Rowden, 2002). Ketidaksesuaian antara peran pekerjaan dan keluarga dapat menimbulkan ketegangan dan perasaan negatif terhadap pekerjaan. Tingkat kepuasan kerja seseorang juga ditentukan oleh persepsi bahwa pekerjaannya mengancam peran pada domain lainnya atau tidak. Jika pekerjaan dirasakan mengancam perannya dalam keluarga, maka akan menimbulkan ketegangan dan perasaan negatif terhadap pekerjaan (Grandey et al., 2005).

\section{Kepuasan Keluarga}

Kepuasan keluarga merupakan persepsi terhadap kualitas peran pada domain keluarga, yang digambarkan dengan perasaan-perasaan positif terhadap keluarga (Parasuraman dan Simmers, 2001), yang berhubungan dengan reaksi emosional terhadap pengalaman sehari-hari sebagai pasangan suami atau istri, atau sebagai orang tua (Frone et al. 1992). Konflik pekerjaan keluarga berpengaruh negatif terhadap kepuasan keluarga (Ahmad, 1996). Seseorang yang bekerja harus mampu membagi waktu dan perhatian secara proporsional antara pekerjaan dan keluarganya. Namun ketika tuntutan pekerjaan meningkat, hal itu menyebabkan seseorang sulit membagi waktu dan perhatiannya secara proporsional, yang kemudian akan menyebabkan turunnya kepuasan keluarga, begitu juga sebaliknya.

Hipotesis keterbatasan (scarcity hypothesis) dalam teori peran menyatakan bahwa waktu dan energi seseorang terbatas sehingga konflik antar peran mempengaruhi kesejahteraan. Konflik pekerjaan-keluarga sebagai salah satu bentuk konflik antar peran berpengaruh terhadap kesejahteraan seseorang. Dimensi pertama dari konflik pekerjaan-keluarga adalah konflik berdasarkan waktu. Konflik berdasarkan waktu akan mempengaruhi kesejahteraan karena penambahan waktu untuk melakukan peran pada satu domain akan mengurangi waktu seseorang untuk memenuhi peran yang lain. Semakin banyak waktu yang dicurahkan untuk satu domain, semakin berkurang waktu yang tersedia untuk beraktivitas pada domain yang lain. Setiap orang berusaha memenuhi peranperan yang melekat pada dirinya dan memiliki ekspektasi pada masing-masing peran. Namun, ketika salah satu peran menuntut perhatian dan pemenuhan yang lebih, akan menyulitkan pemenuhan peran yang lain. Ketika salah satu peran tidak terpenuhi dengan baik, menyebabkan munculnya perasaan kecewa pada diri seseorang. Perasaan kecewa itu menimbulkan perasaan tidak puas atau paling tidak mengurangi perasaan puas karena dia tidak dapat memenuhi peran dirinya seperti yang dia harapkan. Karena kepuasan dalam domain pekerjaan disebut kepuasan kerja, berarti kepuasan kerja menurun/terganggu karena adanya konflik berdasarkan waktu. Sedangkan pada domain keluarga, konflik berdasarkan waktu 
menyebabkan terganggunya kepuasan keluarga. Berdasarkan uraian tersebut, dirumuskan hipotesis sebagai berikut.

Hipotesis 1a: konflik berdasarkan waktu berpengaruh negatif terhadap kepuasan kerja

Hipotesis $1 \mathrm{~b}$ : konflik berdasarkan waktu berpengaruh negatif terhadap kepuasan keluarga

Dimensi konflik pekerjaan-keluarga yang kedua adalah konflik berdasarkan ketegangan. Konflik berdasarkan ketegangan berhubungan dengan lingkungan pada domaindomain dimana seseorang memiliki peran. Tekanan dari lingkungan, baik lingkungan kerja maupun keluarga membuat seseorang menjadi tertekan sehingga muncul ketegangan. Menurut MacEwen dan Barling (1988), ketegangan akan mengakibatkan munculnya emosi negatif, seperti mudah marah dan tersinggung. Emosi negatif tersebut dapat terbawa dari satu domain ke domain yang lain. Bentuk ketegangan yang dimaksud diantaranya adalah kelelahan, depresi, mudah marah/tersinggung, dan apatis. Ketegangan yang muncul pada salah satu peran mempersulit pemenuhan peran pada domain yang lain. Ketegangan menyebabkan seseorang merasa tidak nyaman sehingga kurang/tidak berkonsentrasi dalam menjalankan/memenuhi peran baik pada domain pekerjaan maupun keluarga. Ketegangan pada salah satu peran mempengaruhi kondisi psikologis seseorang. Terlebih lagi ketika seseorang mengalami kesulitan atau tidak dapat mengendalikan emosi negatifnya, menyebabkan pemenuhan peran menjadi kurang optimal, tidak seperti yang dia inginkan. Selanjutnya, konflik berdasarkan ketegangan akan menurunkan kepuasan kerja dan keluarga. Berdasarkan uraian tersebut, dirumuskan hipotesis sebagai berikut.
Hipotesis 2a: konflik berdasarkan ketegangan berpengaruh negatif terhadap kepuasan kerja

Hipotesis 2b: konflik berdasarkan ketegangan berpengaruh negatif terhadap kepuasan keluarga

\section{Gambar 1. Model Penelitian}

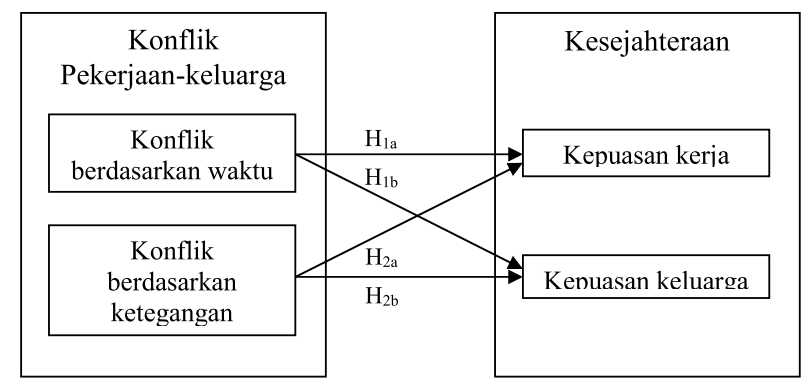

\section{METODE PENELITIAN}

Populasi dalam penelitian ini adalah kepala sekolah di Daerah Istimewa Yogyakarta. Sampel dalam penelitian ini adalah kepala SMA/SMK/ MA baik negeri maupun swasta. Ukuran sampel dalam penelitian ini adalah 100 pasangan. Sampel penelitian diambil dengan menggunakan metode non-probability sampling, dengan teknik purposive sampling (menggunakan kriteria). Kriteria yang digunakan yaitu sudah menikah/berumah tangga dan bertempat tinggal di rumah yang sama selama $\geq 2$ tahun untuk melihat keberadaan komitmen atas hubungan (Hammer et al., 2003). Data diperoleh dengan menggunakan metode survei melalui pengisian kuesioner self-administered. Data persepsi konflik pekerjaan-keluarga dalam penelitian ini didapatkan dari persepsi pasangan/dyad. Kuesioner yang disebarkan sebanyak 107 buah. Dari 107 kuesioner tersebut, 105 kuesioner yang kembali. Dengan demikian tingkat respon dalam penelitian ini adalah $98 \%$. 


\section{Pengukuran}

Item-item dalam kuesioner penelitian ini menggunakan 5 poin skala Likert, dari "sangat tidak setuju (1)" hingga "sangat setuju (5)". Variabel independen dalam penelitian ini adalah konflik berdasarkan waktu dan ketegangan. Konflik berdasarkan waktu diukur menggunakan enam item sedangkan konflik berdasarkan ketegangan diukur menggunakan delapan item, yang mana item-item kuesioner kedua variabel tersebut sebelumnya digunakan oleh Parasuraman et al., (1992). Variabel dependen dalam penelitian ini adalah kepuasan kerja dan keluarga. Kepuasan kerja dan keluarga masing-masing diukur menggunakan lima item pernyataan, yang dikembangkan oleh Brayfield dan Rothe's (1951). Khusus untuk mengukur kepuasan keluarga, kata "kerja" pada item pernyataan yang mengukur kepuasan kerja diganti dengan kata "keluarga". Dalam penelitian ini, peneliti juga menggunakan variabel kontrol; yaitu jenis kelamin, pasangannya bekerja atau tidak, umur, dan jumlah anak. Pengujian validitas instrumen penelitian dilakukan dengan faktor analisis. Item yang digunakan dalam penelitian adalah item yang mempunyai nilai factor loading $\geq 0,5$. Sedangkan untuk uji reliabilitas, peneliti menggunakan kriteria menurut Sekaran (2006), bahwa nilai Cronbach's alpha 0,8 - 1,0 berarti memiliki reliabilitas baik; $0,6-0,79$ berarti reliabilitas diterima; dan $<0,6$ menunjukkan bahwa reliabilitas buruk.

\section{Analisis Data}

Unit analisis dalam penelitian ini pasangan (dyad) untuk mengisi sebagian critical gap yang terjadi dalam studi konflik pekerjaan-keluarga (Parasuraman dan Greenhaus, 2002; Greenhaus, 2008). Bila konflik pekerjaan-keluarga diukur menggunakan self-report, akan menimbulkan bias
(Grant-Vallone dan Donaldson, 2001; Grandey et al., 2005). Pengujian hipotesis dilakukan dengan teknik analisis regresi berganda. Untuk menguji pengaruh moderasi, peneliti menggunakan dasar pengujian yang dilakukan oleh Baron dan Kenny (1986).

\section{HASIL PENELITIAN DAN PEMBAHASAN}

Secara umum, mayoritas responden adalah kepala sekolah laki-laki (82 orang atau sebesar $82 \%$ ), dengan rata-rata umur 50 tahun, memiliki 2 anak, dan 80\% memiliki pasangan yang juga bekerja. Tabel 1 menyajikan ratarata (mean), standar deviasi, dan korelasi antar variabel dalam penelitian ini.

Hasil pengolahan data statistik deskriptif variabel-variabel dalam penelitian menunjukkan bahwa responden mengalami konflik pekerjaan-keluarga pada tingkat rendah, baik pada konflik berdasarkan waktu maupun ketegangan. Hal ini dapat diketahui dari nilai rata-rata konflik berdasarkan waktu sebesar 2,25 dan konflik berdasarkan ketegangan sebesar 1,93. Nilai rata-rata konflik tersebut menunjukkan adanya kecenderungan bahwa responden mempersepsikan tingkat konflik yang rendah. Nilai rata-rata untuk variabel kepuasan menunjukkan angka yang relatif tinggi. Kepuasan kerja bernilai 3,91 sedangkan kepuasan keluarga bernilai 4,26. Tabel 4.3 menunjukkan bahwa korelasi antara konflik pekerjaan-keluarga dan kesejahteraan dalam penelitian ini sesuai dengan teori. Konflik berdasarkan waktu berhubungan dengan kepuasan kerja $(\mathrm{r}=-0,291 ; p<0,01)$ dan keluarga $(\mathrm{r}=-0,329 ; p<0,01)$. Konflik berdasarkan ketegangan ditemukan berkorelasi dengan kepuasan kerja $(\mathrm{r}=-0,313 ; p<0,01)$, dan keluarga $(\mathrm{r}=-0,442 ; p<0,01)$. 
Tabel 1

Mean, Standar Deviasi, dan Korelasi Antar Variabel

\begin{tabular}{|l|c|c|c|c|c|c|}
\hline Variabel & $\mathrm{M}$ & $\mathrm{SD}$ & $\mathrm{KBW}$ & $\mathrm{KBK}$ & $\mathrm{KKJ}$ & $\mathrm{KKL}$ \\
\hline $\begin{array}{l}\text { Pekerjaan } \\
\text { pasangan } \\
\text { Jenis kelamin }\end{array}$ & 4,70 & 2,596 & 0,103 & $-0,078$ & 0,050 & $-0,036$ \\
Umur & 50,33 & 6,457 & $-0,073$ & $-0,200^{*}$ & 0,143 & 0,014 \\
responden & 2,39 & 1,163 & $-0,134$ & $-0,217^{*}$ & 0,096 & 0,022 \\
Jumlah anak & 2,25 & 0,471 & & $0,685^{* *}$ & $-0,291^{* *}$ & $-0,329 * *$ \\
KBW & 1,93 & 0,401 & & & $-0,313^{* *}$ & $-0,442^{* *}$ \\
KBK & 3,91 & 0,569 & & & & $0,480 * *$ \\
KKJ & 4,26 & 0,509 & & & & \\
KKL & 4,02 & 0,430 & & & & \\
\hline
\end{tabular}

$* \mathrm{P}<0,05$

** $\mathrm{P}<0,01$

Tabel 2

Hasil Pengujian Hipotesis Menggunakan Regresi

\begin{tabular}{|l|c|c|c|c|c|c|}
\hline \multirow{2}{*}{$\begin{array}{c}\text { Variabel } \\
\text { Independen }\end{array}$} & \multicolumn{3}{|c|}{ Kepuasan Kerja } & \multicolumn{3}{c|}{ Kepuasan Keluarga } \\
\cline { 2 - 7 } & $\beta$ & $\mathrm{t}$ & Sig & $\beta$ & $\mathrm{T}$ & Sig \\
\hline $\begin{array}{l}\text { Pekerjaan } \\
\text { pasangan }\end{array}$ & 0,120 & 1,246 & 0,216 & 0,013 & 0,131 & 0,896 \\
Jenis kelamin & $-0,240$ & $-2,684$ & $0,009^{* *}$ & $-0,133$ & $-1,474$ & 0,144 \\
Umur & 0,064 & 0,677 & 0,500 & $-0,071$ & $-0,739$ & 0,462 \\
Jumlah anak & $-0,051$ & $-0,529$ & 0,598 & $-0,070$ & $-0,727$ & 0,469 \\
KBW & 1,380 & 1,292 & 0,200 & 1,090 & 1,009 & 0,316 \\
KBK & $-3,072$ & $-2,714$ & $0,008^{* *}$ & $-1,232$ & $-1,076$ & 0,285 \\
\hline
\end{tabular}

$* \mathrm{P}<0,05$

$* * \mathrm{P}<0,01$

Hasil regresi pengujian hipotesis disajikan pada tabel 2. Sedangkan ringkasan hasil pengujian hipotesis disajikan pada tabel 3. Hipotesis 1a memprediksi bahwa terdapat pengaruh negatif konflik berdasarkan waktu terhadap kepuasan kerja. Penelitian ini tidak menemukan adanya pengaruh negatif konflik berdasarkan waktu terhadap kepuasan kerja $(\beta=1,380, P>0,05)$. Berarti hipotesis 1a yang menyatakan bahwa konflik berdasarkan waktu berpengaruh negatif terhadap kepuasan kerja, tidak terdukung dalam penelitian ini. Hasil penelitian ini tidak konsisten dengan penelitian Lambert et al. (2006) yang menemukan bahwa konflik berdasarkan waktu berpengaruh negatif terhadap kepuasan kerja. Jam kerja yang terlalu tinggi atau jadwal kerja yang berbenturan dengan kepentingan keluarga atau tanggung jawab sosial (misalnya: merawat anak dan kegiatan-kegiatan sosial) menyebabkan pekerja sosial memandang pekerjaannya kurang menyenangkan, sehingga kepuasan kerjanya terganggu (menurun). Namun hasil penelitian ini konsisten dengan penelitian O'Driscoll et al. (1992) yang menemukan bahwa tuntutan waktu tidak berpengaruh terhadap kepuasan kerja. Tidak terbuktinya pengaruh negatif konflik berdasarkan waktu terhadap kepuasan kerja diduga karena tekanan pekerjaan yang berbedabeda. Tekanan pekerjaan tersebut mempengaruhi tingkat konflik yang dirasakan seseorang. Ketika konflik yang dirasakan seseorang berada pada tingkat yang rendah, seseorang tidak terkendala untuk tetap memenuhi perannya dalam pekerjaan. Rendahnya konflik yang dipersepsikan tersebut diduga karena pengaruh jenis kelamin responden (mayoritas respoden adalah laki-laki). Jadi, konflik berdasarkan waktu tidak selalu akan berpengaruh negatif terhadap kepuasan kerja. Kepuasan kerja seseorang tidak ditentukan oleh seberapa banyak waktu yang diberikan untuk menyelesaikan pekerjaannya. Kepuasan kerja merupakan persepsi seseorang mengenai seberapa baik pekerjaannya atau merupakan persepsi seseorang mengenai apakah suatu pekerjaan sesuai dengan yang dia harapkan. Jadi, tuntutan waktu bukan merupakan faktor utama yang mempengaruhi kepuasan kerja seseorang.

Dalam penelitian ini, konflik berdasarkan waktu tidak berpengaruh signifikan terhadap kepuasan kerja karena konflik pekerjaan-keluarga yang dialami responden berada pada level yang rendah atau sedang. Tingkatan konflik tersebut diduga karena pekerjaan tidak hanya diselesaikan di tempat kerja tetapi juga diselesaikan di luar jam kerja. Hal ini menyebabkan rendahnya 
tuntutan waktu untuk menyelesaikan pekerjaan. Penelitian ini menggunakan data cross-sectional yang merupakan persepsi atas konflik yang dirasakan saat ini, sehingga kurang menangkap fenomena konflik yang sesungguhnya dialami. Selain itu, instrumen pengukuran kepuasan kerja yang digunakan bersifat umum, tidak mengungkap aspek-aspek lain yang merupakan bagian dari kepuasan kerja, seperti kepuasan akan supervisor, rekan kerja, promosi, gaji, dan lingkungan kerja, sehingga kepuasan kerja yang sesungguhnya belum semuanya terungkap. Diduga seseorang memiliki kemampuan membagi waktu untuk masing-masing peran, dan juga melakukan segmentasi sehingga walaupun harus memenuhi lebih dari satu peran, kepuasan kerjanya tidak terganggu. Segmentasi merupakan salah satu mekanisme yang digunakan untuk melihat interaksi antara domain pekerjaan dan domain keluarga. Segmentasi memandang bahwa keluarga dan pekerjaan tidak terkait sama sekali. Seseorang melakukan segmentasi tujuannya adalah untuk meminimalkan bahkan meniadakan penularan/penyebaran akibat dari tuntutan waktu antar peran. Tuntutan waktu tidak mempengaruhi pemenuhan peran yang terkait dengan pekerjaan. Masalah pada satu domain tidak dibawa dalam domain yang lain. Sehingga, kepuasan kerja tidak terganggu oleh tuntutan waktu tersebut.

Faktor lain yang diduga menyebabkan tidak terdukungnya hipotesis 1a yaitu faktor jenis kelamin responden dan kontekstual di Indonesia. Pertama, hasil pengujian regresi menunjukkan bahwa jenis kelamin (sebagai salah satu variabel kontrol dalam penelitian ini) berpengaruh signifikan terhadap kepuasan kerja. Hal ini memperkuat dugaan bahwa hipotesis 1a tidak terdukung karena mayoritas responden dalam penelitian ini adalah laki-laki (82\%) yang umumnya mengalami atau mempersepsikan konflik pekerjaan-keluarga pada tingkatan yang lebih rendah daripada wanita. Dugaan tersebut sesuai dengan gender role theory yang menyatakan bahwa wanita lebih mengalami atau mempersepsikan konflik pekerjaankeluarga daripada laki-laki. Kedua, kontekstual di Indonesia yang dimaksud adalah keluarga memiliki arti yang sangat luas. Di Indonesia, bila seseorang yang sudah menikah masih tinggal bersama orang tua atau keluarga besarnya merupakan sesuatu yang lazim. Selain itu, banyak keluarga di Indonesia yang memiliki pembantu rumah tangga untuk menyelesaikan pekerjaan dan tanggung jawab yang terkait dengan rumah. Kedua hal tersebut diduga menjadi penyebab tidak terdukungnya hipotesis 1a.

Berdasarkan pada tabel 2, diketahui bahwa konflik berdasarkan waktu tidak berpengaruh terhadap kepuasan keluarga $(\beta=1,090 ; P>0,05)$. Maka, hipotesis $1 \mathrm{~b}$ (konflik berdasarkan waktu berpengaruh negatif terhadap kepuasan keluarga) tidak terdukung dalam penelitian ini. Hasil tersebut sejalan dengan hasil penelitian O'Driscoll et al. (1992) yang menemukan bahwa tuntutan waktu tidak berpengaruh signifikan terhadap aktivitas-aktivitas yang tidak berhubungan dengan pekerjaan. Sebagaimana yang terjadi pada hipotesis $1 \mathrm{a}$, tidak terdukungnya hipotesis $1 \mathrm{~b}$ diduga disebabkan karena tidak semua pekerjaan memiliki tekanan yang sama, tergantung pada masing-masing profesi dan diduga jenis kelamin berpengaruh terhadap persepsi konflik. Selain itu, diduga seseorang memiliki kemampuan untuk melakukan segmentasi, sehingga dalam tekanan waktu seseorang tetap dapat memisahkan antara urusan pekerjaan dan keluarga yang kemudian menyebabkannya tetap dapat memenuhi peran dalam pekerjaan dan keluarga sesuai dengan yang dia harapkan. Jadi, konflik berdasarkan waktu tidak selalu berpengaruh terhadap kepuasan keluarga. Sebaliknya, hasil penelitian ini bertentangan dengan hasil penelitian Ibrahim dan Marri (2008), yang menemukan bahwa konflik pekerjaan-keluarga berpengaruh signifikan terhadap kepuasan keluarga. Hasil penelitian tersebut sesuai dengan teori peran yang 
menyatakan bahwa konflik pekerjaan-keluarga berpengaruh negatif terhadap kesejahteraan. Sama halnya dengan penjelasan mengenai pengaruh konflik berdasarkan waktu terhadap kepuasan kerja, konflik berdasarkan waktu tidak berpengaruh terhadap kepuasan keluarga karena seseorang memiliki kemampuan membagi waktu untuk masing-masing peran, dan juga melakukan segmentasi. Segmentasi merupakan salah satu mekanisme yang digunakan untuk melihat interaksi antara domain pekerjaan dan domain keluarga. Segmentasi memandang bahwa keluarga dan pekerjaan tidak terkait sama sekali. Seseorang melakukan segmentasi tujuannya adalah untuk meminimalkan bahkan meniadakan penularan/penyebaran akibat dari tuntutan waktu antar peran. Tuntutan waktu tidak mempengaruhi pemenuhan peran yang terkait dengan keluarga. Sehingga, kepuasan keluarga tidak terganggu oleh tuntutan waktu tersebut. Ketika seseorang telah terbiasa berada di bawah tekanan/tuntutan waktu, dia memiliki berbagai alternatif untuk tetap bisa memenuhi baik peran pada pekerjaan, maupun peran dalam keluarga (tuntutan waktu tidak menjadi kendala untuk memenuhi peran). Faktor lain yang diduga menyebabkan tidak terbuktinya pengaruh konflik berdasarkan waktu terhadap kepuasan kerja yaitu tidak semua orang memiliki tekanan yang sama, tergantung pada keadaan masing-masing pekerjaan dan kondisi keluarga. Perbedaan tekanan tersebut menyebabkan seseorang mengalami konflik pada tingkatan yang berbeda-beda. Sampel dalam penelitian ini (kepala sekolah), menyelesaikan pekerjaan tidak hanya pada jam kerja (saat di sekolah) saja tetapi juga di luar jam kerja. Sehingga tuntutan waktu pekerjaan tersebut tidak menimbulkan konflik berdasarkan waktu pada tingkatan yang tinggi. Dugaan lain mengenai rendahnya konflik yang dialami atau dipersepsikan oleh responden yaitu mayoritas responden dalam penelitian ini adalah laki-laki (82\%) yang umumnya mengalami atau mempersepsikan konflik pekerjaan-keluarga pada tingkatan yang lebih rendah daripada wanita. Hal ini sesuai dengan gender role theory yang menyatakan bahwa wanita lebih mengalami atau mempersepsikan konflik pekerjaan-keluarga daripada laki-laki.

Hasil regresi pada tabel 2 menunjukkan bahwa konflik berdasarkan ketegangan berpengaruh negatif terhadap kepuasan kerja ( $\beta$ $=-3,072, P<0,01)$. Berarti, sesuai dengan teori peran, konflik pekerjaan-keluarga berpengaruh negatif terhadap kesejahteraan. Semakin tinggi konflik berdasarkan ketegangan yang dialami seseorang, semakin rendah kepuasan kerja. Dengan demikian, hipotesis $2 \mathrm{a}$ terdukung. Hasil penelitian ini sejalan dengan hasil penelitian yang dilakukan oleh Ahmad (1996), yang menunjukkan bahwa konflik pekerjaankeluarga berpengaruh negatif terhadap kepuasan kerja. Tetapi hasil penelitian ini bertentangan dengan hasil penelitian Lambert et al. (2006) yang menyatakan bahwa konflik berdasarkan ketegangan tidak berpengaruh terhadap kepuasan kerja $(\beta=-0,120 ; P>0,05)$. Temuan dalam penelitian Lambert et al. (2006) tersebut disebabkan karena pengukuran yang digunakan dalam penelitian tersebut kurang tepat untuk mengukur bentuk ketegangan secara spesifik. Hal ini menyebabkan konflik berdasarkan ketegangan tidak berpengaruh signifikan terhadap kepuasan kerja. Selain itu, ketegangan yang dialami seseorang bervariasi pada berbagai konteks pekerjaan. Kesimpulannya, pengaruh ketegangan terhadap kesejahteraan seseorang berbeda-beda sesuai dengan tingkat ketegangan dan tuntutan yang dialami seseorang. Sebagaimana yang telah disebutkan dalam hasil penelitian, temuan dalam penelitian Lambert et al. (2006) tersebut disebabkan karena pengukuran yang digunakan dalam penelitian tersebut kurang tepat untuk mengukur bentuk ketegangan secara spesifik, sehingga ketegangan yang dimaksud tidak dapat diidentifikasi. Hal ini menyebabkan konflik berdasarkan ketegangan tidak berpengaruh 
terhadap kepuasan kerja. Selain itu, ketegangan yang dialami seseorang bervariasi pada berbagai konteks pekerjaan, yang kemudian menyebabkan konflik yang dialami seseorang tidak sama.

Tekanan dalam diri seseorang dipengaruhi oleh lingkungan pada domain-domain dimana seseorang memiliki peran. Tekanan tersebut memunculkan ketegangan. Ketegangan pada salah satu domain mempersulit pemenuhan peran pada domain yang lain. Ketegangan menyebabkan seseorang kurang/tidak berkonsentrasi dalam menjalankan/memenuhi perannya dalam pekerjaan. Sesuai dengan scarcity hypothesis dalam teori peran, akhirnya pemenuhan peran menjadi tidak optimal dan tidak seperti yang dia harapkan. Hal ini merupakan additive effect yaitu semakin banyak jumlah domain yang dipersepsikan penuh tekanan, dan semakin meningkat jumlah pemicu tekanan, maka semakin besar dampaknya terhadap kesejahteraan individu (Parasuraman et al., 1992). Jadi, konflik berdasarkan ketegangan berpengaruh negatif terhadap kepuasan kerja. Semakin tinggi konflik berdasarkan ketegangan yang dialami seseorang, maka semakin rendah kepuasan kerjanya.

Bertentangan dengan hasil penelitian Ahmad (1996), penelitian ini menyatakan bahwa konflik berdasarkan ketegangan tidak berpengaruh terhadap kepuasan keluarga ( $\beta$ $=-1,232 ; P>0,05)$. Berarti, hipotesis $2 \mathrm{~b}$ tidak terdukung. Namun, hasil penelitian ini mendukung hasil penelitian Parasuraman et al. (1992) yang menunjukkan bahwa konflik pekerjaan-keluarga tidak berpengaruh terhadap kepuasan keluarga $(\beta$ $=0,02 ; P>0,05)$. Diduga faktor jenis kelamin mempengaruhi persepsi konflik seseorang yang menyebabkan tidak terdukungnya pengaruh negatif konflik berdasarkan ketegangan terhadap kepuasan keluarga. Selain itu, seseorang diduga melakukan segmentasi sehingga ketegangan yang dialami dalam pekerjaan tidak mempengaruhi kepuasan keluarga. Dengan kata lain, walaupun seseorang mengalami ketegangan, dia tetap dapat memenuhi peran dalam keluarga seperti yang dia harapkan. Perbedaan tekanan yang dialami seseorang diduga menyebabkan tidak terbuktinya pengaruh konflik berdasarkan ketegangan terhadap kepuasan keluarga. Perbedaan tekanan tersebut menyebabkan ketegangan yang dialami setiap orang juga berbeda-beda sesuai dengan kondisi keluarga dan pekerjaan. Konflik pada tingkat yang rendah tidak berpengaruh terhadap kepuasan keluarga. Gender role theory menyatakan bahwa wanita lebih mengalami atau mempersepsikan konflik pekerjaan-keluarga daripada laki-laki. Sehingga, rendahnya konflik yang dialami atau dipersepsikan oleh responden dalam penelitian ini disebabkan karena 82\% responden adalah laki-laki yang mengalami atau mempersepsikan konflik pekerjaan-keluarga pada tingkatan yang lebih rendah daripada wanita. Selain itu, diduga orang yang mengalami keteganganmelakukan segmentasiataupemisahan urusan/masalah pekerjaan dan keluarga, sehingga konflik berdasarkan ketegangan tidak terbukti mempengaruhi kepuasan keluarga. Walaupun mengalami konflik berdasarkan ketegangan, seseorang tetap memenuhi berbagai tuntutan peran yang melekat pada dirinya. Diduga, konflik berdasarkan ketegangan bukan merupakan faktor utama yang mempengaruhi kepuasan keluarga seseorang, tetapi dipengaruhi oleh faktor-faktor lain.

Tabel 3

\section{Ringkasan Hasil Pengujian Hipotesis Penelitian}

\begin{tabular}{|c|c|c|c|c|}
\hline Hipotesis & Deskripsi Hubungan & B & Sig & Hasil \\
\hline H1a & $\begin{array}{l}\text { KBW } \rightarrow \\
\text { Kepuasan kerja }\end{array}$ & 1,380 & 0,200 & $\begin{array}{l}\text { Tidak } \\
\text { terdukung }\end{array}$ \\
\hline H1b & $\begin{array}{l}\text { KBW } \rightarrow \\
\text { Kepuasan keluarga }\end{array}$ & 1,090 & 0,316 & $\begin{array}{l}\text { Tidak } \\
\text { terdukung }\end{array}$ \\
\hline $\mathrm{H} 2 \mathrm{a}$ & KBK Kepuasan kerja & $-3,072$ & $0,008^{* *}$ & Terdukung \\
\hline $\mathrm{H} 2 \mathrm{~b}$ & $\begin{array}{l}\text { KBK } \rightarrow \\
\text { Kepuasan keluarga }\end{array}$ & $-1,232$ & 0,285 & $\begin{array}{l}\text { Tidak } \\
\text { terdukung }\end{array}$ \\
\hline
\end{tabular}




\section{KESIMPULAN DAN SARAN}

Kesimpulanyangdapatditarikberdasarkan hasil penelitian ini yaitu konflik berdasarkan waktu tidak mempengaruhi kepuasan kerja dan keluarga. Hal ini tidak sesuai dengan teori peran yang menyatakan bahwa ketidaksesuaian tuntutan waktu berpengaruh terhadap kesejahteraan (kepuasan kerja dan keluarga). Konflik berdasarkan ketegangan berpengaruh negatif terhadap kepuasan kerja (sesuai dengan teori peran), tetapi konflik berdasarkan ketegangan tidak berpengaruh terhadap kepuasan keluarga (tidak sesuai dengan teori peran). Beberapa keterbatasan dalam penelitian ini adalah ukuran sampel yang relatif kecil, menggunakan teknik non-random sampling dan data cross-sectional, serta kecerdasan emosional diukur secara selfadministered (diisi sendiri oleh responden).

Saran yang peneliti ajukan untuk penelitian yang akan datang yaitu penelitian yang akan sebaiknya menggunakan sampel yang heterogen dan didapatkan dengan menggunakan teknik random sampling. Desain riset longitudinal study membantu memahami fenomena yang diteliti atau untuk lebih jelas mengetahui hubungan sebab akibat, dapat menggunakan desain riset eksperimen. Penelitian ini menemukan bahwa jenis kelamin berpengaruh signifikan terhadap kepuasan kerja, sehingga penelitian selanjutnya sebaiknya memperhatikan pengaruh jenis kelamin. Selain jenis kelamin, penelitian selanjutnya mengenai topik konflik pekerjaankeluarga juga perlu memperhatikan konteks di Indonesia.

\section{DAFTAR PUSTAKA}

Ahmad, A. 1996. "Associations of workfamily conflict, job satisfaction, family satisfaction and life satisfaction", Journal of Social Science and Humaniora, Vol. 4, No.2, pp. 101-108.
Astuti, Catharina WR. 2004. Pengaruh pemoderasian dukungan sosial terhadap hubungan antara stressor peran dengan well-being. Magister Sains Fakultas Ekonomika dan Bisnis, UGM. Tesis.

Baruch, G. K, dan Barnett, R. 1986. "Role quality, multiple role involvement, and psychological well-being in midlife women", Journal of Personality and Social Psychology, Vol. 51, No. 3, pp. 578-585.

Brayfield, A. H., dan Rothe, H. F. 1951. "An index of job satisfaction", Journal of Applied Psychology, Vol. 35, No. 5, pp. 307-311.

Cooke, R. A., dan Rousseau, D. M. 1984. "Stress and strain from family roles and workrole expectations". Journal of Applied Psychology, Vol. 69, No. 2, pp. 252-260.

Frone, M. R, Russell, M., dan Cooper, M. L. 1992. "Antecedents and outcomes of work-family conflict: testing a model of the work-family interface", Journal of Applied Psychology, Vol. 77 No.1, pp. 65-78.

Grandey, A. A., Cordeiro, B. L., dan Crouter, A. N. 2005. "A longitudinal and multi-source test of the work-family conflict and job satisfaction relationship", Journal of Occupational and Organizational Psychology, Vol.78, pp. 305-323.

Grant-Vallone, E. J, dan Donaldson, S. I. 2001. "Consequences of work-family conflict on employee well-being over time", Work and Stress, Vol. 15, No. 3, pp. 214226.

Greenhaus, J. H., dan Beutell, N. J. 1985. "Sources of conflict between work and family roles", Academy of Management Review, Vol. 10, No. 1, pp. 76-88.

Greenhaus, J. H. 2008. "Innovations in the study of the work-family interface: introduction to the special section", Journal of 
Occupational and Organizational Psychology, Vol. 81, pp. 343-348.

Greenhaus, J. H, dan Powell, G. N. 2006. "When work and family are allies: a theory of work-family enrichment", Academy of Management Review, Vol. 31, No. 1, pp. 72-92.

Ibrahim, M. E., dan Marri, A. A. 2008. "Consequences of work-family conflict among married employees in uae", University of Sharjah Journal for Humanities \& Social Sciences, Vol. 5, No. 1, pp. 19-39.

Juariyah, Lohana. 2006. Efek saling silang konflik pekerjaan-keluarga terhadap perilaku withdrawal dan well-being pasangan suami istri yang bekerja: analisis dyadic, individual, dan gender. Magister Sains Fakultas Ekonomika dan Bisnis, UGM. Tesis.

Lambert, E. G. et al. 2006. "The impact of workfamily conflict on social work and human service worker job satisfaction and organizational commitment: an exploratory study", Administration in Social Work, Vol. 30 No.3, pp. 55-74.

MacEwen, K. E., dan Barling, J. 1988. "Interrole conflict, family support and marital adjustment of employed mothers: a short term longitudinal study", Journal of Organizational Behavior. Vol. 9, pp. 241-250.

Nollen, S. D. 1986. "Business programs for workfamily problems", Labor Law Journal, Agustus, pp. 480-484.

Noor, N. M. 2002. "Work-family conflict, locus of control, and women's well-being: test of alternative pathways", The Journal of Social Psychology, Vol. 142, No.5, pp. 645-662.
Parasuraman, S., dan Greenhaus, J. H. 2002. "Toward reducing some critical gaps in work-family research", Human Resource Management Review, Vol. 12, pp. 299-312.

Parasuraman, S., dan Simmers, C. A. 2001. "Type of employment, work family conflict and well-being: a comparative study", Journal of Organizational Behavior, Vol. 22, pp. 551-568.

Parasuraman, S., Greenhaus, J. H., dan Granrose, C. S. 1992. "Role stressors, social support, and well-being among two-career couples", Journal of Organizational Behavior, Vol. 13, pp. 339-356.

Rizzo, J. R., House, R. J., dan Lirtzman, S. I. 1970. "Role conflict and ambiguity in complex organizations", Administrative Science Quarterly, Vol. 15, No.2, pp. 150-163.

Rowden, R. W. 2002. "The relationship between workplace learning and job satisfaction in u.s. small to midsize businesses", Human Resource Development Quarterly, Vol. 13, No. 4, p. 407-425.

Sekaran, U. 2006. Research Methods for Business: A Skill Building Approach. Fourth edition. John Wiley \& Sons, New York.

Singh, M., dan Woods, S. A. 2008. "Predicting general well-being from kecerdasan emosional and three broad personality traits", Journal of Applied Social Psychology, Vol. 38 No. 3, pp. 635-646.

Yang, N., Chen, C. C., Choi, J., dan Zou, Y. 2000. "Sources of work-family conflict: a sino-US comparison of the effects of work and family demands", Academy of Management Journal, Vol. 43, No. 1, pp. 113-123. 